\title{
Medical relief during the Nepal earthquake: Observations and lessons to learn
}

\author{
Ramachandra Kamath ${ }^{1}$, Edmond Fernandes ${ }^{2}$, Prakash Narayanan ${ }^{3}$ \\ ${ }^{1}$ Professor; Associate Professor ${ }^{3}$; Department of Public Health, Manipal University, Manipal, India. ${ }^{2} \mathrm{CEO}$, Center for Health and \\ Development, Mangaluru, Karnataka, India.
}

\section{Introduction}

Nepal was hit by earthquake of magnitude 7.8 on Richter scale around 11:56 a.m local time on April 25, 2015 causing injuries, disabilities, deaths and structural damage. ${ }^{1}$ The earthquake struck in central Nepal at a shallow depth of approximately 15 kilometers $(\mathrm{km})$, according to the US Geological Survey. The epicenter of the earthquake was located approximately $77 \mathrm{~km}$ northwest of Kathmandu, Nepal's capital city, and $73 \mathrm{~km}$ east of Pokhara, another major population center. More than 20 aftershocks, ranging between magnitude 4.5 and 6.6, followed the initial earthquake. A fresh earthquake happened on 12 May (magnitude of 7.2) creating extra burden to the country in terms of rescue and relief. The Government of Nepal (GoN) had declared a state of emergency and requested international assistance. ${ }^{2}$ More than 7000 people were killed by the Nepal quake based upon media reports and initial estimates of the government.

Over the years, fields of disaster, crisis and emergency studies have made great strides, however the international relief community is being pushed to the brink by unparalleled intensity, frequency and scale of natural disasters and catastrophes. ${ }^{3-5}$ Earthquakes (including tsunamis) killed more people than all other types of disaster put together, claiming nearly 750,000 lives between 1994 and 2013. ${ }^{6}$ With repeated earthquakes taking place, it shows the gravity of depth through which professionals working in Disaster Risk Reduction need to approach the situations.

The Association of Medical Doctors of Asia (AMDA) International has been pioneering in disaster relief work worldwide since 1984. AMDA has an international network of 30 chapters and 47 collaborating organizations around the world to respond to humanitarian emergencies. ${ }^{7}$ The paper aims at discussing the ground problems and the manner in which relief teams can task themselves towards effective medical relief, through the Nepal earthquake relief work experience.

\section{Affected areas and medical relief camp}

The districts of Gorkha, Nuwakot, Sindhupalchowk, Rasuaa, and Kathmandu Valley (Bhaktapur, Lalitpur, Katmandu) in Nepal were worst affected by earthquake. International medical relief teams were rushed to the affected zones immediately after the initial rapid assessment was done. The AMDA International medical team included doctors, nurses and pharmacists from India, Japan, Cambodia, Philippines, Nepal and Bangladesh were involved in the relief operations in worst affected districts. As a unique model, the AMDA divided the team members into 4 groups to provide relief in 4 worst affected districts. These groups were further sub-divided into urban, rural and mobile teams to cover all terrains in the district. A central village in the district was identified for easy accessibility to the victims and a medical relief camp was established to provide medical relief.

\section{Relief operations in Nuwakot district}

A make shift camp base was established in Kabilash village of Nuwakot district. This village is located in the hilly terrains about $41 \mathrm{kms}$ from Kathmandu, the capital city of Nepal. The area comprised a population of 6000 , about 1200 households and was divided into 9 administrative wards.

Of 1200 houses in Kabilash village, almost $90 \%$ of them were damaged and 45 of them totally destroyed. Houses in the villages were built by stone and mud and the roofs were attached with slates. The major damages to the households were on the upper portion of the houses (roofing) and cracks were seen on the walls. All 3 temples in the neighborhood and all 6 schools in the village were totally damaged. A case in point is casualties in village areas were less as it was a day time quake and people were at work in their fields and being a holiday, children were also playing outdoor games. People were dependent on natural water springs for drinking and for sanitation needs.

In the villages, the villagers were under-prepared, as they had not experienced such incidences before and they were never exposed to disaster preparedness drills. There was no communication reaching them, due to the difficult geographical terrain and the roads were kutcha in nature. Aftershocks were felt on regular intervals, and during such aftershocks, people were advised to remain in the open areas. Small makeshift tents were created near houses in every village and animal shelters were converted as places to rest. It was noted that, while food stock existed at some houses, yet they preferred relief material from national and international agencies.

While responding to this disaster, most of the relief

Correspondence: Dr Edmond Fernandes, CEO, Center for Health and Development, Mangaluru, Karnataka, India. Email: edmondvirgo@gmail.com. 
material reached late and there was a gross shortage of tents. Some aid agencies did not provide medical relief, but were supplying blankets and plastic sheets besides canned food and other immediate accessories. Government agencies were distributing rice, noodles and biscuits. Distribution of food supplies warranted military intervention as the crowd started fighting for priority distributions. Life at the disaster site was very tough. There was no violence or theft observed around these areas other than during distribution of relief material where military presence was needed.

The camp was attached to the community health center area where voluntary aid agencies were providing relief. Among the health problems presented were injuries, fever, respiratory tract infections, asthma, diarrhea, skin Infections, peptic ulcers and weakness were noted. Majority of the victims lived in fear, anxiety and uncertainty because of repeated aftershocks.

While leaving Nepal, inside the airport, the team felt a fresh earthquake measuring 7.1 on Richter scale. The entire airport was emptied and people were moved to the runway area. It was noted that while running, due to the nature of its panic, elderly people were injured due to the pull and push of the situation.

\section{Challenges in the relief operation}

Disaster response to earthquakes is more inclined towards medical treatment than to prevention, but some aspects can be linked to tertiary prevention where patients whose injuries can be limited are targeted. ${ }^{8}$

The relief operations posed significant challenges such as rains, landslide, hilly terrains where mudflow occurred, poor road connectivity, and language barriers, all of which hindered the process of establishing efficient relief operations in Nepal. Landslides and mudflows were seen during the earthquakes in Tajikstan (1989), Philippines (1990), and Colombia (1994) and it was observed during the Nepal Earthquake which had multiple aftershocks. ${ }^{9}$

Being placed in a vulnerable geography also led to intermittent power failure and electricity was disrupted. Mobile connectivity had suffered greatly and cold weather added to the already existing problems for rescue and relief. This is consistent with the Loma Prieta earthquake in 1989 where area residents cut off from outside had to initially help themselves and then their neighbors to attain safer grounds. ${ }^{10-11}$

\section{Conclusion}

The disaster victims demonstrated great resilience and were back to work the next day, in their own ways. Overall, the relief operations helped in reducing the suffering and illness of the affected population to a considerable extent. Immediate relief operations at their doorsteps provided by various governmental and nongovernmental aid agencies enhanced the hope and mental health of the earthquake victims to overcome the grievances and psychological distress.

\section{Recommendations}

In any post disaster scenario, it is imperative to establish counseling mechanisms at the earliest, because the psychosocial trauma and the sudden shock that the victims experience injects sufficient amount of fear and problems. Earthquake resistant architecture will need to be designed while restructuring the existing ones. Reinforced Cement Concrete Slab (RCC) buildings could be the safe alternative to mud and stone roofing structure in zones where earthquakes recur. Low cost, light weight houses made of wood and metal frames would be better in seismically prone high risk zones. Elderly people need to be taken care of as a priority before women and children because they are deeply vulnerable than most. The needs of the population suddenly deprived of urban and rural services, homes, possessions should assume higher importance as soon as life threatening situation comes under control. Surveillance mechanism for communicable diseases besides addressing injuries should occur simultaneously. People's behavior under stress calls for consistent psychological intervention and military protection to relief health workers.

\section{References}

1. United States Geological Survey. M7.8 - 36km E of Khudi, Nepal. http://earthquake.usgs.gov/ earthquakes/eventpage/us20002926\#general (Accessed May 2016).

2. ITV. Nepali government 'declares state of emergency.' Available at: http://www.itv.com/news/ update/2015-04-25/nepali-government-declaresstate-of-emergency/ (Accessed May 2016).

3. Mileti D. Disasters by Design: A Reassessment of Natural Hazards in the United States. Washington, DC: Joseph Henry Press, 1999.

4. Alexander DE. Natural Disasters. London and New York: UCL Press and Chapman \& Hall, 1993.

5. Prince SH. Catastrophe and social change: Based upon a sociological study of the Halifax Disaster. Stud Hist Econ Public Law 1920; 94:1-152.

6. Relifweb. The human cost of natural disasters 2015: a global perspective. http://reliefweb.int/ report/world/human-cost-natural-disasters-2015global-perspective (Accessed May 2016).

7. AMDA International (March, 2016) Association of Medical Doctors of Asia. http:// amdainternational.com/01 about.html\#Origin (Accessed May 2016).

8. Noji EK, Sivertson KT. Injury prevention in natural disasters: a theoretical framework. Disasters 1987;11(4):290-6.

9. Garcia LE. The Paez, Colombia earthquake of June 6, 1994. Earthquake Eng Res Inst Newsl 1994; 8:7.

10. Pointer JE. The 1989 Loma Prieta Earthquake: impact on hospital care. Ann Emerg Med 1992; 21:1228-33.

11. Palafox J, Pointer JE, Martchenke J, Kleinrock M, Michaelis J. The 1989 Loma Prieta earthquake: Issues in medical control. Prehosp Disaster Med 1993;8:291-7. 